\title{
Pengaruh Mentoring Kajian Dhuha Qatulistiwa Islam Unit Kegiatan Kerohanian Terhadap Akhlak Mahasiswa Universitas Negeri Padang
}

\author{
Rihha Datul Aisy ${ }^{1}$, Sulaiman ${ }^{2}$ \\ rihhada98@gmail.com ${ }^{1}$, sulaiman@fis.unp.ac.id ${ }^{2}$ \\ Universitas Negeri Padang ${ }^{1,2}$
}

\begin{tabular}{|c|c|}
\hline ARTICLE INFO & \multirow{13}{*}{$\begin{array}{l}\text { This study aims to determine the implementation of } \\
\text { moral development in the mentoring of the Dhuha study, then } \\
\text { to determine the effect of mentoring in the dhuha study on the } \\
\text { results of the moral development of Universitas Negeri } \\
\text { Padang students. And to find out the effectiveness of the } \\
\text { implementation of mentoring in the study of dhuha on the } \\
\text { results of moral development of Padang State University } \\
\text { students. The type of research used is field research (field } \\
\text { research) with a quantitative research approach. The results } \\
\text { of this study explain that the mentoring of the Islamic Dhuha } \\
\text { Qatulistiwa Study has an influence on the morals of } \\
\text { Universitas Negeri Padang students. It can be seen from the } \\
\text { simultaneous significant test that the calculated F value = } \\
\text { 23,800 with an F table value of 3.94 with a significance level } \\
\text { of confidence 0.05, thus the Fcount value } 23,800>\text { F-table } 3.94 \text {, } \\
\text { with a significance level of 0.000, it means that there is a } \\
\text { significant effect between the Dhuha Study Mentoring } \\
\text { variable (X) and the Student Morals variable (Y). So there is a } \\
\text { positive and significantrelationship between the mentoring of } \\
\text { the Islamic Dhuha Qatulistiwa Study on the Morals of } \\
\text { Universitas Negeri Padang. }\end{array}$} \\
\hline Article history: & \\
\hline Received, 05 Agustus 2021 & \\
\hline Revised, 17 Februari 2022 & \\
\hline Acce & \\
\hline Keywords: & \\
\hline Mentoring, Akhlak, & \\
\hline Mahasiswa Universitas & \\
\hline Negeri Padang & \\
\hline Conflict of Interest: & \\
\hline None & \\
\hline Funding: & \\
\hline None & \\
\hline
\end{tabular}

Corresponding Author: Rihha Datul Aisy, Department Islamic Education Faculty of Social Science Universitas Negeri Padang, Indonesia, Email: rihhada98@gmail.com, Phone No: $+6282286397168$

Copyright@2022, Author(s)

\section{Pendahuluan}

Pendidikan merupakan hak setiap orang di dunia.Di Indonesia hak tersebut tertuang dalam Pasal 31 ayat 1 UUD 1945 sebagai berikut: "Setiap warga negara berhak mendapatkan pendidikan", dan pada ayat 3 berbunyi "Pemerintah mengusahakan dan menyelenggarakan satu sistem pendidikan nasional, yang meningkatkan keimanan dan ketakwaan serta akhlak mulia dalam mencerdaskan kehidupan bangsa, yang diatur dengan undang-undang".

Pemerintah menginisiasi penyelenggaraan pendidikan karakter (pendidikan karakter mulia) di semua jenjang pendidikan mulai dari sekolah dasar hingga pendidikan tinggi melalui Kementerian Pendidikan. Program pendidikan 
Rihha Datul Aisy dan Sulaiman : Pengaruh Mentoring Kajian Dhuha Qatulistiwa Islam...

individualitas dan nilai-nilai moral yang tinggi telah muncul di kalangan pendidikan Indonesia untuk memperkuat moral dan akhlak, karena selama ini masyarakat percaya bahwa proses pendidikan belum berhasil membentuk manusia Indonesia yang bermoral. Banyak orang mengatakan bahwa pendidikan gagal membentuk moralitas. Banyak lulusan sekolah dan sarjana yang pandai menjawab soal ujian dan memiliki pikiran yang cemerlang, tetapi mental mereka lemah dan pemalu, dan perilaku mereka tidak terpuji. Pendidikan tidak hanya dibebani tugas mencerdaskan anak didik dari segi kognitif saja, akan tetapi kecerdasan dari segi afektif dan psikomotorik tugas harus diperhatikan. Dalam hal ini beban pendidikan yang berkaitan dengan kecerdasan afektif siswa adalah upaya membina moral (akhlak) peserta didik. Moral yang diharapkan adalah moral yang menjunjung tinggi nilai-nilai kemanusiaan yang disandarkan pada keyakinan beragama. Akan tetapi untuk mewujudkan hal tersebut dewasa ini tampaknya banyak kendala yang harus dihadapi. Munculnya isu kemerosotan martabat manusia (dehumanisasi) yang muncul akhir-akhir ini. Dapat diduga akibat krisis moral. Krisis moral terjadi antara lain akibat ketidak berimbangnya antara kemajuan "IPTEK" dan "IMTAQ" (Wajdi, 2016, pp. 69-70).

Berbicara tentang akhlak ini bukan lagi merupakan hal yang tabu, Bahkan Rasulullah SAW selaku pemimpin umat Islam pernah bersabda bahwa beliau diutus sebagai penyempurna akhlak. Oleh karena itu penting adanya pendidikan akhlak dan moral, tidak hanya dalam kegiatan-kegiatan formal seperti di sekolah namun juga diluar kegiatan-kegiatan formal seperti extrakurikuler. Karena Perkembangan zaman yang semakin modren ini, membutuhkan perhatian yang serius terhadap akhlak, jika dibiarkan akan menghancurkan masa depan bangsa dan remaja, merosotnya akhlak anak bangsa, semacam pola hidup hedonistik terus menjadi merasuki para anak muda, pergaulan leluasa (bebas) yang merugikan orang lain serta merugikan dirinya sendiri yang bisa menghancurkan masa depan bangsa dan agama. Oleh sebab itu butuh aksi terhadap arus kehidupan jahiliyah tersebut. Apabila akhlaknya baik, maka baik pula lahir batinnya dan sebaliknya jika jelek akhlaknya, jelek pula lahir batinya. Akhlak merupakan bagian penting yang tidak dapat dipisahkan dalam kehidupan manusia, tanpa akhlak, manusia akan hilang derajat kemanusiaannya sebagai makhluk yang mulia (Sirait, Siddik, \& Zubaidah, 2017, p. 550).

Dengan demikian dapat dipahami bahwa Pendidikan akhlak itu merupakan suatu sikap atau kehendak manusia disertai dengan niat yang tenteram dalam jiwa yang berlandaskan Alquran dan Al-Hadis yang menimbulkan perbuatan-perbuatan atau kebiasaan-kebiasaan secara mudah tanpa memerlukan pembimbingan terlebih dahulu. Jika kehendak jiwa itu menimbulkan perbuatan-perbuatan dan kebiasaankebiasaan yang bagus, maka disebut dengan akhlak yang terpuji. Begitu pula sebaliknya, jika menimbulkan perbuatan-perbuatan dan kebiasaan-kebiasaan yang jelek, maka disebut dengan akhlak yang tercela (Salim, 2001, pp. 56-58). Sebagai bentuk kepedulian untuk mewujudkan masyarakat dan remaja indonesia yang religius dan berakhlak mulia Universitas Negeri Padang juga mensuport kegiatan-kegiatan keislaman lembaga dakwah kampus, baik dari pihak rektorat maupun sivitas akademika Universitas Negeri Padang, seperti dari segi pendanaan yang dialokasikan untuk kegiatan-kegitan keislaman. Salah satunya kegiatan Mentoring Kajian Dhuha yang dilaksanakan oleh sebuah UKM, yaitu Qatulistiwa Islam yang berada dibawah naungan Unit Kegiatan Kerohanian (UKK). 
Qatulistiwa Islam UKK UNP bertujuan untuk membina keimanan, ketaqwaan, akhlak dan moral mahasiswa muslim UNP kepada Allah SWT dalam rangka mewujudkan kampus yang religius dan intelektual. Serta menjadi wadah pengembangan wawasan islam mahasiswa UNP yang berbasis pembinaan dan kompetensi dalam rangka mewujudkan insan akademis yang religius, berakhlakul karimah dan ilmiah menuju masyarakat kampus yang madani. Berdasarkan pengamatan penulis, kegiatan ini memiliki dampak positif kepada mahasiswa Universitas Negeri Padang seperti terdapatnya peningkatan akhlak pada diri mahasiswa, diantaranya terlihat dari pola interaksi dengan dosen, teman sebaya, dan menghormati sivitas akademika dari kalangan bawah seperti Cleaning Service dan sekuriti, serta munculnya sikap toleransi antar satu dengan yang lainnya. Oleh karena dalam tulisan ini akan menggambarkan bagaimana pengaruh Mentoring Kajian Dhuha terhadap akhlak mahasiswa Universitas Negeri Padang.

\section{Tinjauan Pustaka}

Menurut Smith's Mentoring (dalam Maryadi, 2012:6) Mentoring mengacu pada interaksi instruktur (individu yang lebih berpengalaman) dengan peserta mentoring (tujuan atau target instruktur) bertujuan untuk membantu seorang mente/peserta mengembangkan jati dirinya, makin mempertajam ilmu pengetahuan serta perluasan jaringan/koneksi, melejitkan prestasi, serta karier.

Ruswandi dan Maryadi 2012:7 mengemukakan bahwa salah satu sarana tarbiyah islam yaitu mentoring agama islam yang didalamnya ada pembelajaran islam. Arahan pembinaan adalah pembentukan karakter dan kepribadian islami peserta (Syakhsiyah Islamiyah). Terbentuknya kepribadian islami dan pemahaman islam yang merupakan tujuan dan orientasi dari mentoring.

Landasan konseptual mentoring, Islam memiliki sumber utama dalam menetapkan suatu hukum, yaitu Al-Qur'an dan Hadits. Demikian juga, semua aktivitas manusia didasarkan pada dua sumber yang utama tersebut. Ajaran Islam adalah bagian yang tidak terpisahkan dari kegiatan manusia. Oleh karena itu, ketika mentoring dilakukan, ajaran Islam masih berlandaskan pada dua sumber utama norma kehidupan manusia, yaitu Al-Qur'an dan Hadits. Berikut Nash yang berkaitan:

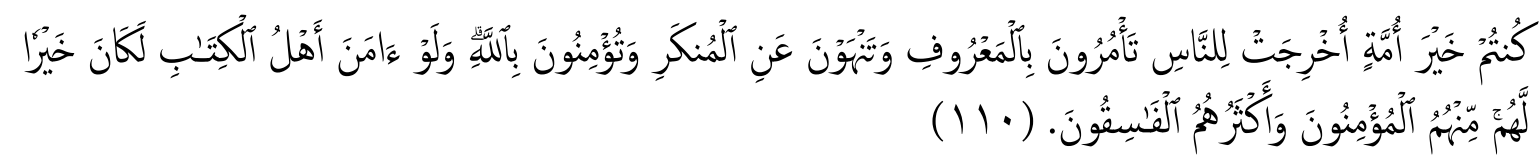

Artinya: "kamu adalah umat yang terbaik yang dilahirkan untuk manusia, menyuruh kepada yang ma'ruf, dan mencegah dari yang munkar, dan beriman kepada Allah. Sekiranya ahli kitab beriman, tentulah itu lebih baik bagi mereka, di antara mereka ada yang beriman, dan kebanyakan mereka adalah orang-orang yang fasik.") QS. Ali-Imran: 110)

Kemudian dalam Hadits Rasulullah SAW bersabda: "Sampaikanlah dariku walau hanya satu ayat".

Kompenen dalam mentoring yaitu: adanya Pesertai mentoring adalah orang-orang direkrut dan mendaftarkan diri untuk aktif mengikuti kegiatan mentoring. Peserta mentoring sering disebut peserta pelatihan atau mutarobbi/mente. Pelaksana mentoring/tarbiyah ialah orang yang berperan selaku pendidik dan pelaksana dalam kegiatan-kegiatan mentoring. Pelaksana mentoring merupakan para imentor yang 
Rihha Datul Aisy dan Sulaiman : Pengaruh Mentoring Kajian Dhuha Qatulistiwa Islam...

biasanya disebut dengan guru/murobbi.kemudian adanya proses yaitu tahapantahapan yang wajib dilalui oleh anggota mentoring, serta adanya lembaga yang menjalankan kegiatan mentoring tersebut.

Tujuan dari mentoring atau tarbiyah, yaitu terciptanya insan (manuasia) yang memiliki profil atau ciri-ciri yang digambarkan dengan sebutan 10 sifat yang harus dimiliki (muwashafat) (dalam Az-zahidda 2009) sebagai berikut: Aqidah yang bersih (Salimul Aqidah), Ibadah yang benar (Shahihul Ibadah), Akhlaq yang kokoh (Matinul Khuluq), Tubuh yang kuat (Qawiyyul Jism), Pandai menjaga waktu (Harishun 'Ala Waqtihi), Pemikiran yang luas (Mutsaqofful Fikri), Tertata Segala Urusannya (Munazhamun Fi Syu'unihi), Mampu Menghidupi Dirinya (Qadiirun 'Alal Kasbi), Bersungguh-Sungguh (Mujahidun Nafsihi), dan Bermanfaat Bagi Orang Lain (Nafi'un Ghairihi).

Akhlaq dalam bahasa Arab adalah خلق - يخلق - أخلآق bentuk jamak dari khuluq, yang mengandung arti watak, perangai, akhlak, atau budi pekerti, menurut Mahmud (2004). Kata akhlak berasal dari kata Arab khalaqa (خلق), yang berarti "menghasilkan", yang memiliki akar kata yang sama dengan khaliq (Pencipta), makhluq (diciptakan), dan khalq (penciptaan). "Akhlaq adalah kualitas yang ditanamkan dalam jiwa yang memungkinkan perbuatan diambil tanpa berpikir atau refleksi," kata Imam al-Ghazali.

Menurut Miswanto \& Arafi dalam bukunya Agama, Keyakinan, dan Etika, akhlak dapat dibagi menjadi dua kategori berdasarkan tujuannya, yaitu akhlak kepada sang pencipta Khaliq (Tuhan) serta akhlak terhadap makhluk/ciptaan Allah SWT, yang meliputi akhlak terhadap manusia dan akhlak terhadap alam atau lingkungan. Adapun tiga aliran pemikiran yang sangat menonjol dalam menjelaskan unsur-unsur yang penyebab terbentuknya moralitas/akhlak. Yang pertama adalah apa yang dikenal sebagai nativisme. Aliran kedua adalah empirisme, dan ketiga adalah konvergensi (Nata, 2015:143).

Komponen terpenting dalam penyebab terbentuknya akhlak seseorang menurut nativisme, yaitu faktor intrinsik seperti kecenderungan, dan kemampuan akal. Selanjutnya, faktor eksternal hal yang sangat mempengaruhi tumbuh kembangnnya diri seseorang, seperti lingkungan masyarakat, termasuk arahan dari lingkungan pendidikan, menurut aliran empirisme. Sementara itu, Aliran konvergensii menyatakan bahwa terbentuknya akhlak seseorang dipengaruhii oleh variabel internal (dalam diri) dan eksternal, yakni sifat anak-anak serta pengaruh eksternal, termasuk pendidikan dan pelatihan, atau kontak sosial.

\section{Metode}

Jenis yang digunakan dalam penilitian ini adalah field research (penelitian Lapangan) menggunakan Metode Kuantitatif. Metode dalam penelitian ini menggunakan metode korelasional. Variabel dalam penelitian ini terdiri dari variabel bebas dan variabel terikat. Variabel bebas pada penelitian ini yaitu Mentoring Kajian Dhuha yang diberi tanda $\mathrm{X}$ dan variabel terikat dalam penelitian ini yaitu akhlak mahasiswa yang diberi tanda Y. Populasi dalam penelitian ini adalah mahasiswa yang sudah mengikuti Mentoring Kajian Dhuha pada tahun ajaran 2020/2021 yang berjumlah sebanyak 2.949 orang mahasiswa. iTeknik pengambilan sampel pada penelitian ini yaitu isecara Random iSampling menggunakan Rumus Slovin sehingga sampel pada penelitian ini adalah sebanyak i97 iorang mahasiswa. Instrumen yang 
idigunakan iuntuk ipengumpulan idata iyaitu iangket/kuisioner imelalui igoogle iform. Uji validitas dengan rumus product moment dan reliabilitas dengan rumus Alpha Crounbach menggunakan program SPSS versi 20. Untuk melakukan analisis data penulis menggunakan Microsoft Exel dan Program SPSS Versi 20.

\section{Hasil dan Pembahasan}

Data akhlak siswa dalam penelitian ini diperoleh dengan metode angket skala likert yang memuat kisi-kisi indikator akhlak siswa. Adapun angket skala likert digunakan untuk mengukur sikap, persepsi/presepsi seseorang atau sekelompok orang tentang fenomena sosial. Lalu dengan menggunakan angket skala likert, maka variabel yang akan diukur dijabarkan menjadi indikator variabel. Kemudian indikator tersebut dijadikan sebagai tolak ukur untuk menyusun item-item instrumen yang dapat berupa pernyataan atau pertanyaan.

Dari penelitian yang telah dilakukan di Qatulistiwa Islam UKK UNP. Hasil analisis nilai angket keaktifan mahasiswa mengikuti kegiatan Mentoring Kajian Dhuha yang telah diberikan kepada 97 responden, diperoleh data nilai keaktifan mahasiswa mengikuti kegiatan Mentoring Kajian Dhuha sebagai berikut: Responden $(N)=97$ dengan data terendah $($ Min $)=31$, dan data tertinggi $($ Max $)=96$, rata-rata $($ Mean $)=78$, median $(M d)=79$, modus $(M o)=85$, standar deviasi $(S D)=10,1$. Data terergolong kedalam kategori data interval dengan Range $(R)=19$. Untuk mengetahui lebih jelas temuan tentang variabel Mentoring Kajian Dhuha bisa dilihat hasil analisis pada tabel berikut:

Tabel 1. Distribusi Frekuensi kategori kegiatan Mentoring Kajian Dhuha

\begin{tabular}{|l|l|l|l|l|}
\hline No & Kategori & $\mathbf{I = 1 9}$ & $\mathbf{F}$ & $\mathbf{\%}$ \\
\hline 1. & $\begin{array}{l}\text { Sangat } \\
\text { Tinggi }\end{array}$ & $85-104$ & 24 & $25 \%$ \\
\hline 2. & Tinggi & $65-84$ & 65 & $67 \%$ \\
\hline 3. & Sedang & $45-64$ & 7 & $7 \%$ \\
\hline 4. & Rendah & $25-44$ & 1 & $1 \%$ \\
\hline & & Total & 97 & $100 \%$ \\
\hline
\end{tabular}

Dari tabel distribusi tersebut diketahui keaktifan mahasiswa mengikuti kegiatan Mentoring Kajian Dhuha di Qatulistiwa Islam UKK Universitas Negeri Padang berada pada kategori sangat baik sebanyak 24 mahasiswa atau 25\%, dalam kategori baik sebanyak 65 mahasiswa atau 67\%, dan dalam kategori sedang sebanyak 7 mahasiswa atau 7\%, serta dalam kategori cukup sebanyak 1 mahasiswa atau 1\%. Sehingga didapat bahwa data kegiatan Mentoring Kajian Dhuha di Qatulistiwa Islam Unit Kegiatan Keislaman (UKK) Universitas Negeri Padang 2020/2021 sebagian besar berada pada kategori sangat baik/baik seperti terlihat pada histogram berikut: 
Rihha Datul Aisy dan Sulaiman : Pengaruh Mentoring Kajian Dhuha Qatulistiwa Islam...

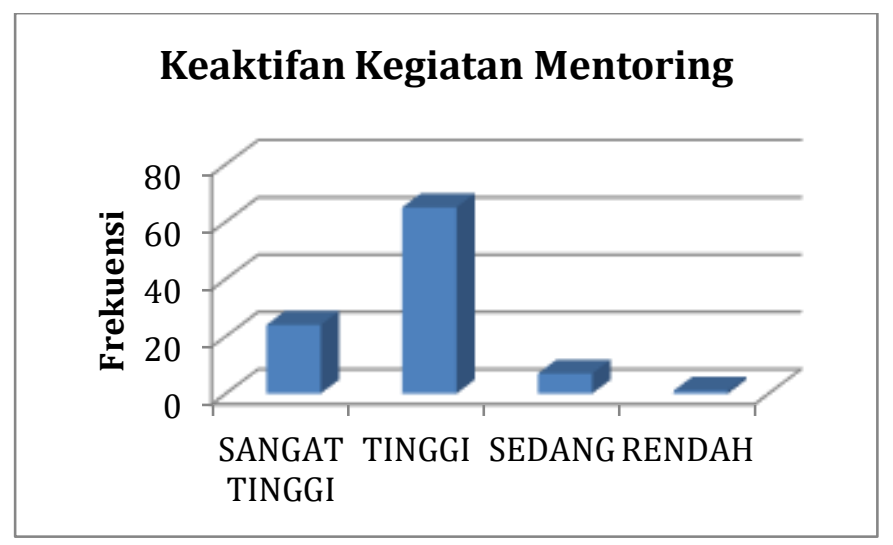

Gambar 1. Histogram Keaktifan mahasiswa dalam kegiatan Mentoring

Dari penelitian yang telah dilakukan di Qatulistiwa Islam Unit Kegiatan Kerohanian (UKK) Universitas Negeri Padang. Hasil analisis nilai angket akhlak mahasiswa Universitas Negeri Padang yang telah diberikan kepada 97 responden, diperoleh data nilai akhlak mahasiswa Universitan Negeri Padang sebagai berikut: Responden $(\mathrm{N})=$ 97 dengan data terendah $(\mathrm{Min})=56$, dan data tertinggi $(\mathrm{Max})=99$, rata-rata $($ Mean $)=$ 76 , median $(\mathrm{Md})=75$, modus $(\mathrm{Mo})=81$, standar deviasi $(\mathrm{SD})=7,8$. Data terergolong kedalam kategori data interval dengan Range $(R)=19$. Untuk mengetahui lebih jelas temuan tentang variabel Akhlak Mahasiswa Universitas Negeri Padang bisa dilihat hasil analisis pada tabel berikut:

Tabel 2. Distribusi Frekuensi kategori Akhlak Mahasiswa Universitas Negeri Padang

\begin{tabular}{|l|l|l|l|l|}
\hline No & Kategori & $\mathbf{I = 1 9}$ & $\mathbf{F}$ & $\mathbf{\%}$ \\
\hline 1. & $\begin{array}{l}\text { Sangat } \\
\text { Tinggi }\end{array}$ & $85-104$ & 12 & $12 \%$ \\
\hline 2. & Tinggi & $65-84$ & 80 & $82 \%$ \\
\hline 3. & Sedang & $45-64$ & 5 & $5 \%$ \\
\hline 4. & Rendah & $25-44$ & 0 & $0 \%$ \\
\hline & & Total & 97 & $100 \%$ \\
\hline
\end{tabular}

Dari tabel distribusi tersebut diketahui akhlak mahasiswa Universitas Negeri Padang berada pada kategori sangat baik sebanyak 12 mahasiswa atau 12\%, dalam kategori baik sebanyak 80 mahasiswa atau 82\%, dan dalam kategori sedang sebanyak 5 mahasiswa atau 5\%, serta dalam kategori cukup sebanyak 0 mahasiswa atau $0 \%$. Sehingga didapat bahwa data akhlak mahasiswa Universitas Negeri Padang 2020/2021 sebagian besar berada pada kategori sangat baik/baik seperti terlihat pada histogram berikut: 


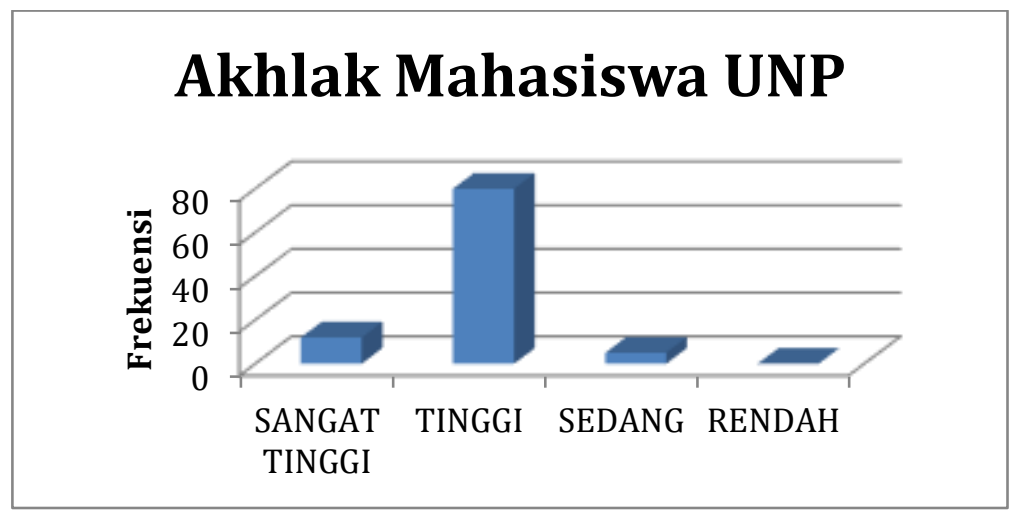

Gambar 2. Histogram Akhlak mahasiswa Universitas Negeri Padang

Untuk mengetahui tingkat hubungan antara Mentoring Kajian Dhuha Qatulistiwa Islam terhadap akhlak mahasiswa Universitas Negeri Padang maka dilakukan uji hipotesis. Uji hipotesis dalam penelitian ini menggunakan teknik korelasi Rank Spearman. Uji hipotesis dilakukan dengan bantuan program SPSS versi 20.

Tabel 3. Korelasi Rank Spearman

\begin{tabular}{|l|l|l|l|}
\hline No & N & $\begin{array}{c}\text { Correlation } \\
\text { Coefficient }\end{array}$ & $\begin{array}{l}\text { Sig. (2- } \\
\text { tailed) }\end{array}$ \\
\hline Mentoring & 97 & $0.528^{* *}$ & 0.000 \\
\hline Akhlak & 97 & $0.528^{* *}$ & 0.000 \\
\hline
\end{tabular}

Untuk kriteria hasil uji hipotesis dalam penelitian ini diketahui dengan melihat output correlation coefficient dan nilai sig. (2-tailed). Jika nilai correlation coefficient $>$ r-tabel maka dinyatakan berkorelasi. Jika nilai sig. $<0,005$ maka dinyatakan tidak berkorelasi. Dari hasil analisis didapat $r$-hitung $=0,528$. Sedangkan $r$-tabel untuk responden $(\mathrm{N})=97$ adalah 0.198 . Karena rhitung 0,528 besar dari $r$-tabel 0.198 , maka Hipotesis Awal (Ha) diterima dan Hipotesis nihil (Ho) ditolak. Jadi diketahui bahwa data memiliki hubungan yang signifikan. Jadi, semakin tinggi keaktifan mahasiswa mengikuti Mentoring Kajian Dhuha semakin tinggi capaian akhlak mahasiswa Universitas Negeri Padang. Artinya tingkat kekuatan korelasi/hubungan antara mentoring kajian dhuha dengan akhlak adalah memiliki hubungan kuat, sesuai tabel berikut;

Tabel 4. Tingkat Korelasi dan Kekuatan Pengaruh

\begin{tabular}{|l|l|l|}
\hline No. & Tingkat Korelasi & Tingkat Pengaruh \\
\hline 1 & $0.00-0.25$ & Hubungan sangat lemah \\
\hline 2 & $0.26-0.50$ & Hubungan cukup \\
\hline 3 & $0.51-0.75$ & Hubungan kuat \\
\hline 4 & $0.76-0.99$ & Hubungan sangat kuat \\
\hline
\end{tabular}


Rihha Datul Aisy dan Sulaiman : Pengaruh Mentoring Kajian Dhuha Qatulistiwa Islam...

\begin{tabular}{|l|l|l|}
\hline 5 & 1.00 & Hubungan sempurna \\
\hline
\end{tabular}

Dari hasil analisis data penelitian pengaruh Mentoring Kajian Dhuha terhadap akhlak mahaisiwa berada pada posisi sangat baik/baik. Artinya mahasiswa sudah menjalankan nilai-nilai akhlak yang baik dalam kehidupan sehari-hari baik dari apek akhlak kepada Allah SWT, akhlak terhadap sesama manusia dan akhlak terhadap lingkungan serta akhlak kepda dosen. Namun belum secara keseluruhan mahasiswa menerapkan nilai akhlak yang baik misal mahasiswa yang suka menolong orang lain dan menjaga kelestarian lingkungan, disuatu sisi malas beribadah dan kurang menurut terhadap orang tua atau guru. Jadi dapat dikatakan akhlak mahasiswa berada pada katergori sedang atau cukup baik.

Akhlak yang baik memiliki kedudukan yang sangat penting dalam individu atau kehidupan bermasyarakat terkhususnya pada diri mahasiswa Universitas Negeri Padang. Apa yang didapat oleh mahasiswa dalam lingkungannya akan dibawa untuk diterapakan di lingkungan mengajar di sekolah nanti jika beprofesi sebagai guru maupun dalam pergaulannya. Karena akhlak itu cerminan diri. Apabila akhlaknya baik, maka baik pula lahir batinnya dan sebaliknya jika jelek akhlaknya, jelek pula lahir batinya. Akhlak merupakan bagian penting yang tidak dapat dipisahkan dalam kehidupan manusia, tanpa akhlak manusia akan hilang derajat kemanusiaannya sebagai makhluk yang mulia (Sirait, Siddik, \& Zubaidah, 2017, p. 550).

Untuk mencapai akhlak baik yang diinginkan di lingkungan masyarakat Universitas Negeri Padang terutama bagi mahasiswa, maka perlunya lingkungan dan lembaga sebagai pengontrol kegiatan mahasiswa. Salah satu dari kegiatan tersebut yaitu dengan adanya sarana tarbiyah berbentuk mentoring mingguan bagi mahasiswa. Sejalan dengan pendapat Ruswandi dan Maryadi (2012) mengemukakan bahwa salah satu sarana tarbiyah islam yaitu mentoring agama Islam yang didalamnya ada pembelajaran islam. Arah mentoring adalah pembentukan karakter dan kepribadian islami masyarakat (Syakhsiyah Islamiyah). Terbentuknya kepribadian islami dan pemahaman islam yang merupakan tujuan dan orientasi dari mentoring.

Dari data hasil penelitian yang diperoleh, bahwa semakin tinggi keaktifan mahasiswa mengikuti mentoring Kajian Dhuha maka semakin tinggi pula pengaruh terhadap akhlak yang diperoleh. Karena tujuan dari mentoring atau tarbiyah, yaitu terciptanya insan (manusia) yang memiliki profil atau ciri-ciri yang digambarkan dengan sebutan 10 sifat yang harus dimiliki (muwashafat) (dalam Az-zahidda 2009) sebagai berikut: Aqidah yang bersih (Salimul Aqidah), Ibadah yang benar (Shahihul Ibadah), Akhlaq yang kokoh (Matinul Khuluq), Tubuh yang kuat (Qawiyyul Jism), Pandai menjaga waktu (Harishun 'Ala Waqtihi), Pemikiran yang luas (Mutsaqofful Fikri), Tertata Segala Urusannya (Munazhamun Fi Syu'unihi), Mampu Menghidupi Dirinya (Qadiirun 'Alal Kasbi), Bersungguh-Sungguh (Mujahidun Nafsihi), dan Bermanfaat Bagi Orang Lain (Nafi'un Ghairihi). Jika tujuan dari kegiatan mentoring ini tercapai, maka secara langsung akhlak mahasiswa pun akan mengikuti pengalaman yang didapat selama mentoring.

Dari observasi awal peneliti di lapangan dan pengalaman selama meneliti di lapangan peneliti melihat masih terdapat akhlak mahasiswa yang kurang baik seperti meribut di kelas, menganggu teman, berkata kasar dan lain-lain. Dari hasil analisis data dan hasil uji hipotesis yang dilakukan diperoleh ada hubungan yang signifikan dan 
positif antara mentoring kajian Dhuha Qatulistiwa Islam UKK dengan akhlak mahasiswa Universitas Negeri Padang. Hal ini bisa dipahami bahwa mentoring kajian Dhuha ikut mendukung capaian akhlak baik mahasiswa Universitas Negeri Padang.

\section{Simpulan}

Berdasarkan hasil penelitian yang telah dilakukan, maka dapat disimpulkan hubungan Mentoring Kajian Dhuha Qatulistiwa Islam UKK terhadap akhlak mahasiswa Universitas Negeri Padang berada pada kategori sangat baik/baik. Artinya terdapat hubungan yang positif dan signifikan antara Mentoring Kajian Dhuha dengan akhlak mahasiswa Universitas Negeri Padang. Hal ini dibuktikan dengan hasil analisis data dengan menggunakan rumus product moment diperoleh rxy 0,528. Sedangkan r-tabel dengan $n=97$ adalah 0.198 . Karena rhitung 0,528 besar dari r-tabel 0.198, maka Hipotesis Awal (Ha) diterima dan Hipotesis nihil (Ho) ditolak. Artinya semakin tinggi keaktifan mahasiswa mengikuti Mentoring Kajian Dhuha semakin tinggi capaian akhlak baik mahasiswa Universitas Negeri Padang. Artinya tingkat kekuatan korelasi/hubungan antara mentoring kajian dhuha dengan akhlak adalah memiliki hubungan kuat.

\section{Referensi}

Az-Zahidda, Wida. 2009. Mentoring Fun. Surakarta: Afra Publishing

Anas, Sudijono. 2014. Pengantar Statistik Pendidikan. Jakarta: Raja Grafindo Persada

A. Abdul Halim Mahmud. 2004. Akhlak Mulia, Jakarta: Gema Insani.

Bukhori. 1959. Shohih al Bukhori. Semarang: Toha Putra

Departemen Agama Republik Indonesia. 1989. Al Qur"an dan Terjemahnya. Semarang : CV Toha Putra

Departemen Pendidikan dan Kebudayaan, 1989. Kamus Besar Bahasa Indonesia. Jakarta: Balai Pustaka

Hasibuan, E. J., Tambunan, N., \& Science, F. (2008). Urgency of Cultivation of Morals in Children in the Era of Globalization in Islamic Perspective AzZahidda, Wida. 2009. Mentoring Fun. Surakarta: Afra Publishing

Halim, N.A. 2000. Menghias diri dengan akhlak terpuji. Yogyakarta: Mitra Pustaka

Hamid, Muhammad Abdul Halim. 2001. Karakteristik \& Perilaku Tarbiyah. Bandung: Asy Syamil Press dan Grafika.

Ilyas, Yunahar. 2014. Kuliah Akhlaq. Yogyakarta: Lembaga Pengkajian dan Pengamalan Islam (LPPI)

Maryadi, dkk. 2012. Risalah Menejemen Mentoring Kampus. Semarang.TIM Kurikulum BK Menas

Miswanto, A \& Arafi, Z. 2012. Agama, Keyakinan dan Etika. Magelang: P3SI UM Magelang

Nasution. S 2011. Metode Research (Penelitian Ilmiah). Jakarta: Bumi Aksara. 
Rihha Datul Aisy dan Sulaiman : Pengaruh Mentoring Kajian Dhuha Qatulistiwa Islam...

Nata, Abuddin. 2015. Akhlak Tasawuf dan Karakter Mulia. Depok: PT Rajagrafindo Persada.

Sirait, I., Siddik, D., \& Zubaidah, S. (2017). Implementasi Pendidikan Akhlak dalam Pengembangan Karakter di Madrasah Aliyah Negeri 1 Medan. Edu Riligia, Volume 1 Nomor 4 .

Salim, A. (2001). Teori dan Paradigma Penelitian Sosial. Yogyakarta: PT Tiara Wacana.

Undang Undang No 20 Tahun 2003 Tentang Sistem Pendidikan Nasional

Wajdi, M. F. (2016). Karamah Tiga Sufi. Jakarta: Qalam Publishing 